\title{
Diet of the toad Rhinella icterica (Anura: Bufonidae) from Atlantic Forest Highlands of southeastern Brazil
}

\author{
Leandro Talione Sabagh ${ }^{1,2,3}$, Ana Maria Paulino Telles Carvalho-e-Silva ${ }^{2} \&$
}

\author{
Carlos Frederico Duarte Rocha
}

${ }^{1}$ Laboratório de Ecologia de Vertebrados, Departamento de Ecologia, Universidade do Estado do Rio de Janeiro - UERJ, Rua São Francisco Xavier, 524, Maracanã, CEP 20550-019, Rio de Janeiro, RJ, Brasil

${ }^{2}$ Laboratório de Biossistemática de Anfibios - LaBAn, Departamento de Zoologia, Universidade Federal do Estado do Rio de Janeiro - UNIRIO, Av. Pasteur, 458, Urca, CEP 22290-240, Rio de Janeiro, RJ, Brasil

${ }^{3}$ Corresponding author: Leandro Talione Sabagh, e-mail: leandro.sabagh@gmail.com

SABAGH, L.T., CARVALHO-E-SILVA, A.M.P.T. \& ROCHA, C.F.D. Diet of the toad Rhinella icterica (Anura: Bufonidae) from Atlantic Forest Highlands of southeastern Brazil. Biota Neotrop. 12(4): http:// www.biotaneotropica.org.br/v12n4/en/abstract?short-communication+bn01612042012

Abstract: In this study, we present some information of the regarding throphic niche from the anuran toad Rhinella icterica living in high altitudes above $2000 \mathrm{~m}$ a.s.l. from a habitat of the Atlantic Forest Biome - the Altitude Fields in the Itatiaia National Park. We found 150 prey items in toad stomachs, belonging to five prey types, as well as skin remains and some remains of plant material. The index of relative importance indicated that most important prey types were beetles and ants, these last composing $70 \%$ of the diet numerically and the trophic niche breadth (B) was 1.81 . The relatively low diversity of prey types we recorded in the diet of R. icterica of Itatiaia and numerically dominated by ants suggests some preference for this item. We do not found significant relationship between the toad measurements with the preys' measurements. We concluded that $R$. icterica toads at the highlands of Itatiaia feeds on arthropods, mainly ants and coleopterans and that the high consumption of preys with relatively small and similar size as ants in the diet prevents an expected relationship among frog body or mouth size and prey volume and size.

Keywords: Amphibia, feeding habits, highlands, trophic niche, Yellow Cururu Toad.

SABAGH, L.T., CARVALHO-E-SILVA, A.M.P.T. \& ROCHA, C.F.D. Dieta do sapo Rhinella icterica (Anura: Bufonidae) em altitudes elevadas na Mata Atlântica do sudeste do Brasil. Biota Neotrop. 12(4): http://www. biotaneotropica.org.br/v12n4/pt/abstract?short-communication+bn01612042012

Resumo: No presente estudo apresentamos informações sobre o nicho trófico de uma espécie de anuro que reside em altitudes elevadas da Mata Atlântica. Descrevemos a dieta do sapo Rhinella icterica em altitudes acima de 2000 m em áreas de Campos de Altitude no Parque Nacional do Itatiaia. Encontramos 150 itens nos estômagos analisados de $R$. icterica, divididos em apenas cinco categorias de presa, além de vestígios da própria pele do anuro e restos vegetais. O índice de importância relativa indicou que besouros e formigas foram os itens mais importantes sendo que formigas representam $70 \%$ dos itens ingeridos. A amplitude de nicho trófico (B) foi de 1,81 . O reduzido número de categorias alimentares, bem como o elevado número de formigas na dieta sugere que $R$. icterica apresente uma preferência por este item. Não encontramos nenhuma relação significativa entre as dimensões do anuro com as dimensões das presas. Concluímos que a população de $R$. icterica que habita os campos de altitude de Itatiaia alimentam-se de artrópodes, principalmente formigas e besouros. $\mathrm{O}$ alto consumo de presas com tamanho relativamente semelhante e pequeno como, por exemplo, formigas, impede uma relação esperada entre o tamanho do corpo do anuro ou o tamanho de sua mandíbula e tamanho e volume de presas.

Palavras-chave: Amphibia, hábitos alimentares, campos de altitude, nicho trófico, sapo Cururu. 


\section{Introduction}

Diet is one of the most important dimensions of an animal species niche (Toft 1985). Along the last two decades an increasing number of studies regarding anurans diet has been developed in Brazil in different Biomes, ecosystems and habitats, including the Pantanal (e.g. Sabagh et al. 2010, Sugai et al. 2012), Cerrado (e.g. Batista et al. 2011, Maragno \& Souza 2011), Amazon (e.g. Juncá \& Eterovick 2007, Sabagh et al. 2012), Caatinga (e.g. Damasceno 2005), and Pampas (e.g. Solé et al. 2002). However, most studies concentrated in the Atlantic Rain Forest (e.g. Siqueira et al. 2006, Santana \& Juncá 2007, Sabagh \& Carvalho-e-Silva 2008, Ferreira $\&$ Teixeira 2009) involved species and populations living in lowland areas (e.g. Boquimpani-Freitas et al. 2002, Siqueira et al. 2006, Almeida-Gomes et al. 2007, Ferreira \& Teixeira 2009, Martins et al. 2010, Almeida-Santos et al. 2011), especially in the ombrophilous forest, with a marked lack of information on anurans feeding habits from highlands. Some studies have investigated the relationship and influence of the size of the frog and the size of prey ingested (e.g. Sabagh \& Carvalho-e-Silva 2008, Duré et al. 2009, Quiroga et al. 2009, Batista et al. 2011, Maragno \& Souza 2011) as an ontogenetic diet shift.

Rhinella icterica (Spix, 1824) has a relatively wide distribution in South America occurring from eastern Paraguay and Misiones, Argentina, along Southern (Rio Grande do Sul) and Southeastern northwards to Bahia in northeastern and Goiás in central Brazil (Frost 2011), occurring in different habitats and altitudes along the Atlantic forest Biome. At the highlands of the National Park of Itatiaia we found one population of $R$. icterica occurring in the "Campos de altitude" (Altitude Fields) ecosystem. Campos de altitude constitutes the southeastern Brazilian highlands above 2,000 m elevation in the Atlantic Forest. The characteristics of this habitat, mainly mediated by low temperatures, also results in a high rate of flora and fauna endemism (Safford 1999, 2007), although relatively little is known in terms of ecology of the species from these mountaintop formations (Safford 1999).

The knowledgement on $R$. icterica feeding habits is considerably restricted and available data for Atlantic Forest indicates that it has a relatively diversified diet including a high number of ants (Sabagh \& Carvalho-e-Silva 2008). In the present study, we provide the first information regarding the diet of a population of $R$. icterica living in an area of high elevation (above 2,000 $\mathrm{m}$ a.s.l.) in the Itatiaia National Park (Brazil). We aimed to specifically answer the following questions: i) Which food items make up the diet of this $R$. icterica population? ii) Which are the main prey types consumed by this toad?; iii) Which is the niche breadth of this population? iv) There are relationship between the toad body size and the prey size? v) Do the diet of this $R$. icterica population is similar to other populations and other species of the genus?

\section{Materials and Methods}

The study was carried out the Itatiaia National Park of (PNI) located between the states of Rio de Janeiro and Minas Gerais (in Serra da Mantiqueira) in southeastern Brazil. Samples were collected specifically in two areas: Brejo da Lapa $\left(22^{\circ} 21^{\prime} \mathrm{S}\right.$ and $44^{\circ} 44^{\prime} \mathrm{W}$, $2,000 \mathrm{~m}$ a.s.1.), and Abrigo Rebouças ( $22^{\circ} 23^{\prime} \mathrm{S}$ and $44^{\circ} 40^{\prime} \mathrm{W}$, 2,450 m a.s.1.). Abrigo Rebouças is a true Campo de Altitude formation, whereas Brejo da Lapa can be considered as a transition between upper mountain forest and Campos de Altitude (Safford 1999). The mean temperature variation in the area is $7.4-13.6{ }^{\circ} \mathrm{C}$ and the annual rainfall ranges from 1,500-3,000 $\mathrm{mm}$ (Safford 1999). In terms of vegetation, the "Campos de Altitude" constitutes a mosaic of dispersal shrubs and small copses of short, often stunted trees set within a more continuous matrix of bunchgrasses and bamboo (Safford 1999).

Collections were made at night during August 2005 (dry season). Toads were collected manually, anesthetized with clorethone, and had their stomach flushed (Leclerc \& Courtois 1993). The food items obtained from stomach-flushing method were preserved in alcohol $70 \%$. We measured the snout-vent length (SVL), and jaw width (JW) of toads using a caliper ( $0.1 \mathrm{~mm}$ precision). After sampling the stomach contents by flushing and taking biometric variables, the individual toads were kept in captive until recover from anesthesia, and were returned to the exact site of the habitat where they were previously found.

Diet composition was determined based on number $(\mathrm{N})$, volume $(\mathrm{V})$ and occurrence $(\mathrm{O})$ of each prey type in the stomachs. The length and width of each prey item were measured with caliper $(0.1 \mathrm{~mm}$ precision) and its volume (in $\mathrm{mm}^{3}$ ) was estimated using the ellipsoid formulae (Dunham 1983). An index of relative importance (IRI $=\% O$. $(\% \mathrm{~N}+\% \mathrm{~V}))$ of each prey category in the diet was estimated according Pianka et al. (1971). Food niche breadth was calculated using the formula proposed by Levins (1968) $\mathrm{B}=1 / \Sigma \mathrm{pi}^{2}$, where $\mathrm{B}=$ niche breadth and pi $=$ proportion of item $\mathrm{i}$ in the diet in order to allow comparison with a value of food niche breadth calculated in a previous study for another population of R. icterica (Sabagh \& Carvalho-eSilva 2008). The values of niche breadth were standardized $\left(B_{A}\right)$ to a restrict of 0 to 1 using the appropriate formula, $B_{A}=(B-1) /(n-1)$, where $\mathrm{B}_{\mathrm{A}}=$ standardized Levins index and $\mathrm{n}=$ number of possible resources.

To evaluate if toad snout-vent length or jaw width affects prey size consumed we used a simple linear regression using body variables as independent variables and prey-items size as dependent variables (Zar 1999). We specifically analyzed the relationships SVL $\times$ total volume of preys per stomach, JW x the largest prey volume per stomach, and $\mathrm{JW} \times$ largest prey length per stomach. The values of prey items were $\ln$-transformed for meet normality and homogeneity. We used the value of 0.05 as the cut-off for significance.

We used the individual-based rarefaction method (Gotelli \& Colwell 2001) to validate the comparison between the richness of prey (orders) of two $R$. icetrica populations from PNI (data from present study) and Serra dos Órgãos National park - PARNASO (data from Sabagh \& Carvalho-e-Silva 2008) even with samples being distinct sizes (Bonansea \& Vaira 2007). The rarefaction curves (with standard deviation) and the Jacknife 1 richness estimator were done performing 1,000 randomizations without replacement using the software EstimateS 8.2 (Colwell 2009).

\section{Results and Discussion}

We sampled 17 individuals of Rhinella icterica, three of which $(16.7 \%)$ had empty stomachs. We found 150 arthropods items in five prey categories as food items in the stomachs (Table 1). Also, in one stomach $(5.9 \%)$ we found parts of skin of R. icterica. The occurrence of own skin in the stomachs of $R$. icterica has been also found in other studies regarding Rhinella species (Evans \& Lampo 1996, Teixeira et al. 1999, Sabagh \& Carvalho-e-Silva 2008) and it seems to constitutes a common habit among amphibians, which recycle their skin during molting (Weldon et al. 1993). Remains of plant material were found in 10 stomachs $(58.8 \%)$. We found small stones in the stomach of three individual toads (17.7\%). The occurrence of these two last items are common and probably they were ingested accidentally as suggested in many diet studies of Rhinella species (e.g. Evans \& Lampo 1996, Teixeira et al. 1999, Sabagh \& Carvalhoe-Silva 2008, Isaacs \& Hoyos 2010). 
Sabagh, L.T. et al.

Table 1. Diet composition of Rhinella icterica toad $(\mathrm{n}=17)$ in the highlands of the Itatiaia National Park, Itatiaia Municipality, Rio de Janeiro State, Brazil, with respective absolute and relative values of abundance $(\mathrm{N}$ and $\% \mathrm{~N})$, occurrence $(\mathrm{O}$ and $\% \mathrm{O})$, volume $(\mathrm{V}$ and $\% \mathrm{~V})$, and index of relative importance $(\mathrm{IRI})$ of each prey categories.

\begin{tabular}{lccccccc}
\hline \multicolumn{1}{c}{ Itens } & $\mathbf{N}$ & $\mathbf{\% N}$ & $\mathbf{O}$ & $\mathbf{\% O}$ & $\mathbf{V}\left(\mathbf{m m}^{\mathbf{3}}\right)$ & $\mathbf{\%} \mathbf{V}$ & $\mathbf{I R I}$ \\
\hline Coleoptera & 37 & 24.7 & 11 & 64.7 & 8566.4 & 60.1 & 54.84 \\
Hymenoptera (Formicidae) & 105 & 70.0 & 9 & 52.9 & 3197.3 & 22.4 & 48.93 \\
Odonata & 2 & 1.3 & 1 & 5.9 & 1561.3 & 10.9 & 0.72 \\
Opiliones & 3 & 2.0 & 2 & 11.8 & 462.8 & 3.2 & 0.62 \\
Aranae & 3 & 2.0 & 3 & 17.7 & 194.9 & 1.4 & 0.59 \\
Unidentified remains & - & - & 1 & 5.9 & 276.0 & 1.9 & - \\
Skin remains & - & - & 1 & 5.9 & - & - & - \\
Plant remains & - & - & 10 & 58.8 & - & - \\
\hline
\end{tabular}

Formicidae dominated the diet numerically $(70.0 \%)$, although in terms of volume $(60.1 \%)$ and occurrence $(64.7 \%)$ Coleoptera was the most representative item in the $R$. icterica diet (Table 1). Supplementary food items as Opiliones, Araneae and Odonata nymphs were consumed in comparatively lower frequency (Table 1). The data indicated that $R$. icterica population at the highlands of Itatiaia National Park fed on arthropods, mainly on ants and coleopterans, in a similar way to what has been found to the diet of other species in the genus Rhinella (Lajmanovich 1994, Isacch \& Barg 2002, Sabagh \& Carvalho-e-Silva 2008, Duré et al. 2009, Ferreira \& Teixeira 2009, Isaacs \& Hoyos 2010). These results suggested that toads of the genus Rhinella tend to feed predominantly on these arthropods, even living in different ecosystems along the distribution of the species and of the genus. Formicidae usually constitute dominant arthropod organisms among those living in the leaf-litter of the forest floor of the Atlantic forest biome (Lacerda et al. 1998, Santos et al. 1998) and is the most representative item in the diet of other Rhinella species (Toft 1980, Evans \& Lampo 1996, Teixeira et al. 1999, Isacch \& Barg 2002, Sabagh \& Carvalho-e-Silva 2008, Duré et al. 2009, Ferreira \& Teixeira 2009, Quiroga et al. 2009, Maragno \& Souza 2011). However, some species of Rhinella have beetles as the most important item in the diet (Lajmanovich 1994, Grant 1996, Duré et al. 2009, Isaacas \& Hoyos 2010, Batista et al. 2011). The population of $R$. icterica at Itatiaia highlands follows the pattern of the genus having ants and beetles as the most representative items in your diet (Table 1).

The relatively low number of prey types (only five) in the diet of $R$. icterica in PNI highlands, was comparatively lower than that found for the same species studied in an area about $995 \mathrm{~m}$ a.s.l. of PARNASO (Figure 1) to which diet was composed by 21 order of preys (Sabagh \& Carvalho-e-Silva 2008). This variation in diet richness found among these studies may reflect differences in food availability between areas, periods of collection or even altitudes. In fact, it is well known that invertebrate availability decreases with an increase in altitude (Leakey \& Proctor 1987, Brühl et al. 1999, Almeida-Neto et al. 2006) and thus, we do not know in which extent a supposedly lower availability of arthropods in the highlands of PNI could explain part of these observed differences in number of prey size consumed among $R$. icterica populations. However, the similarities are that ants and beetles showed the most values items in the diet of the species in both localities. Even without showing a confidence interval, $R$. icterica of PNI showed a relative greater standard trophic breadth $\left(\mathrm{B}_{\mathrm{A}}=0.20 ; \mathrm{B}=1.81\right)$ when compared with the same species in PARNASO $\left(\mathrm{B}_{\mathrm{A}}=0.03\right)$ (Sabagh \& Carvalho-e-Silva 2008). The Levins index resumes information about consumed preys richness and evenness, thus, we would be expected that $R$. icterica in PNI had a more equitative prey distribution in its diet because had less prey types. We believe that $R$. icterica is a non-selective feeder then dietary

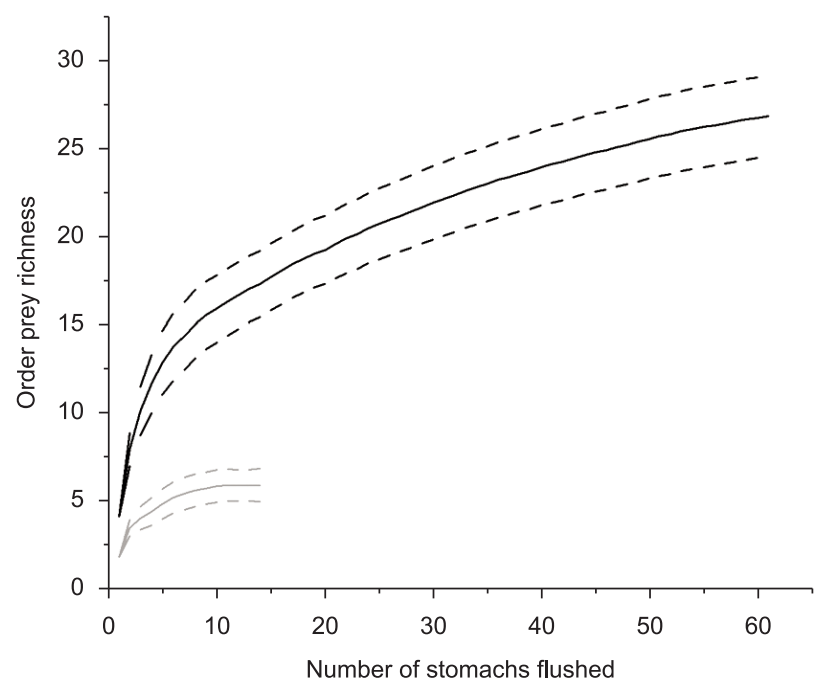

Figure 1. Rarefaction curves with their respective standard deviation for two population of Rhinella icterica. Highlands of Itatiaia National Park (gray lines) and Serra dos Órgãos National Park (black lines), southeastern Brazil.

differences found between populations may reflect, at list in part, the availability of preys as proposed for other Rhinella species (Evans \& Lampo 1996) and bufonids (Bonansea \& Vaira 2007).

The total volume of preys found in stomachs varied from 160.2 to $4,240.0 \mathrm{~mm}^{3}$ and the largest prey volume varied from 17.7 (an ant) to $4,021.2 \mathrm{~mm}^{3}$ (a beetle). In terms of length, the largest prey items in the stomachs varied from $6.0 \mathrm{~mm}$ (a spider) to $36.6 \mathrm{~mm}$ (a dragonfly nymph). Mean SVL of R. icterica sampled measured $114.5 \pm 8.1 \mathrm{~mm}$ $($ range $=101.3-128.7 \mathrm{~mm})$ with a mean $\mathrm{JW}=41.1 \pm 1.9 \mathrm{~mm}$ (range $=37.7-44.8 \mathrm{~mm}$ ). There was no significant relationship between total prey volume and toad SVL $\left(\mathrm{F}=1.31 ; \mathrm{R}^{2}=0.098\right.$; $\mathrm{p}=0.275)$, between the largest prey volume and JW $(\mathrm{F}=0.02$; $\left.\mathrm{R}^{2}=0.002 ; \mathrm{p}=0.886\right)$, and between largest prey length and toad JW $\left(\mathrm{F}=0.24 ; \mathrm{R}^{2}=0.020 ; \mathrm{p}=0.633\right)$. Amphibians usually ingest their prey whole and as result, mouth dimensions tend to restrict the upper limit of prey size they can consume (Blackburn \& Moreau 2006). This relationship is generally reflected in many Rhinella species by a positive relationship between mouth size and prey dimensions (e.g. Duré et al. 2009, Quiroga et al. 2009, Batista et al. 2011, Maragno \& Souza 2011), which was not observed for R. icterica in our study. The absence of a significant relationship between the prey size ingested and $R$. icterica size at Itatiaia National Park may be the result from the high consumption of ants, which are preys of small size and little size variation (which reduces the total prey volume in the toads' diets). This trend has been also found in Leptodactylus marmoratus 
(Steindachner, 1867) from the Atlantic rainforest of Ilha Grande in Rio de Janeiro (Almeida-Gomes et al. 2007) to which most of diet was composed by ants, and also for the lizard Cnemidophorus littoralis Rocha et al. 2000, for which the absence of this relationship seemed to be due to the large consumption of termites (Teixeira-Filho et al. 2003). The difference of $27.4 \mathrm{~mm}$ between the highest and lowest toad and $7.1 \mathrm{~mm}$ between the highest and lowest jaw may not have been sufficient to establish a relationship with diet. The $R$. icterica population of PARNASO showed a positive and significant relationship between the toad body size and their total prey volume, however the difference between the highest and lowest toad was $92.2 \mathrm{~mm}$, and the low value of $\mathrm{r}^{2}$ is not enough to prove diet ontegeny (Sabagh \& Carvalho-e-Silva 2008).

We concluded that Rhinella icterica toads at the highlands of Itatiaia National Park fed a few orders of arthropods, mainly on ants and coleopterans. Last two were also the main preys of PARNASO population and other species of the genus. The high consumption of preys with relatively small and similar size as ants in the diet prevents an expected relationship among frog body or mouth size and mean prey size. Future studies should work with a higher altitude gradient to test the hypothesis of differences in the frogs' diet.

\section{Acknowledgements}

We thank P.N. Costa, R.A. Marques, S.P. Carvalho-e-Silva, M.M. Mongin, and V.G.D. Orrico for assistance in the field, and C.C. Siqueira and two anonymous referees for helpful suggestions. This study was supported by Projeto de Conservação e Utilização Sustentável da Diversidade Biológica Brasileira (PROBIO) and Ministério do Meio Ambiente (MMA) (Proc. 2001CV000101). The Coordenação de Aperfeiçoamento de Pessoal de Nível Superior (CAPES) provided financial support to L.T.S. CFDR received resources from the $\mathrm{CNPq}$ (processes 304791/2010-5 and 470265/2010-8), and FAPERJ (program "Cientistas do Nosso Estado"; E-26/102.404/2009).

\section{References}

ALMEIDA-GOMES, M., VAN-SLUYS, M. \& ROCHA, C.F.D. 2007. Ecological observations on the leaf-litter frog Adenomera marmorata in an Atlantic rainforest area of southeastern Brazil. Herpetol. J. 17:81-85.

ALMEIDA-NETO, M., MACHADO, G., PINTO-DA-ROCHA, R. \& GIARETTA, A.A. 2006. Harvestman (Arachnida: Opiliones) species distribution along three Neotropical elevational gradients: an alternative rescue effect to explain Rapoport's rule? J. Biogeogr. 33:361-375. http:// dx.doi.org/10.1111/j.1365-2699.2005.01389.x

ALMEIDA-SANTOS, M., SIQUEIRA, C.C., VAN-SLUYS, M. \& ROCHA, C.F.D. 2011. Ecology of the Brazilian Flea Frog Brachycephalus didactylus (Terrarana: Brachycephalidae). J. Herpetol. 45:251-255. http://dx.doi. org/10.1670/10-015.1

BATISTA, R.C., BRITO-DE-CARVALHO, C., FREITAS, E.B., FRANCO, S.C., BATISTA, C.C., COELHO, W.A. \& FARIA, R.G. 2011. Diet of Rhinella schneideri (Werner, 1894) (Anura: Bufonidae) in the Cerrado, Central Brazil. Herpetol. Notes 4:17-21.

BLACKBURN, D.C. \& MOREAU, C.S. 2006. Ontogenetic diet change in the arthroleptid frog Schoutedenella xenodactyloides. J. Herpetol. 40(3):388-394. http://dx.doi.org/10.1670/00221511(2006)40[388:ODCITA]2.0.CO;2

BONANSEA, M.I. \& VAIRA, M. 2007. Geographic variation of the diet of Melanophryniscus rubriventris (Anura: Bufonidae) in Northwestern Argentina. J. Herpetol. 41(2):231-236. http://dx.doi.org/10.1670/00221511(2007)41[231:GVOTDO]2.0.CO;2
BOQUIMPANI-FREITAS, L., ROCHA, C.F.D. \& VAN-SLUYS, M. 2002. Ecology of the Horned Leaf-Frog, Proceratophrys appendiculata (Leptodactylidae), in an insular Atlantic Rain-Forest Area of Southeastern Brazil. J. Herpetol. 36(2):318-322.

BRÜHL, C.A., MOHAMED, M. \& LINSENMAIR, K.E. 1999. Altitudinal distribution of leaf litter ants along a transect in primary forests on Mount Kinabalu, Sabah, Malaysia. J. Trop. Ecol. 15:265-277. http://dx.doi org/10.1017/S0266467499000802

COLWELL, R.K. 2009. Free software application of biodiversity functions, estimators, and indexes based on biotic sampling data. http://viceroy.eeb. uconn.edu/EstimateS/ (último acesso em 10/09/2012).

DAMASCENO, R. 2005. Uso de recursos alimentares e eletividades na dieta de uma assembléia de anuros terrícolas das dunas do médio Rio São Francisco, Bahia. Biota Neotrop. 5(1): http://www.biotaneotropica.org.br/ v5n2/pt/abstract?article+BN02405022005 (último acesso em 05/12/2011)

DUNHAM, A.E. 1983. Realized niche overlap, resource abundance, and intensity of interspecific competition. In Lizard Ecology: studies of a model organism (R.B. Pianka \& T. Schoener, eds). Harvard University Press, p.261-280.

DURÉ, M.I., KEHR, A.I. \& SCHAEFER, E.F. 2009. Niche overlap and resource partitioning among five sympatric bufonids (Anura, Bufonidae) from northeastern Argentina. Phyllomedusa 8(1):27-39.

EVANS, M. \& LAMPO, M. 1996. Diet of Bufo marinus in Venezuela. J. Herpetol. 30(1):73-76. http://dx.doi.org/10.2307/1564710

FERREIRA, R.B. \&. TEIXEIRA, R.L. 2009. Feeding pattern and use of reproductive habitat of the Striped toad Rhinella crucifer (Anura: Bufonidae) from Southeastern Brazil. Acta Herpetol. 4(2):125-134.

FROST, D.R. 2011. Amphibian Species of the World: an Online Reference. Version 5.5 (31 January, 2011). American Museum of Natural History, New York. http://research.amnh.org/vz/herpetology/amphibia/index.php (último acesso em 11/11/2011).

GOTELLI, N.J. \& COLWELL, R.K. 2001. Quantifying biodiversity: procedures and pitfalls in the measurement and comparison of species richness. Ecol. Lett. 4: 379-391. http://dx.doi.org/10.1046/j.14610248.2001.00230.x

GRANT, G.S. 1996. Prey of the introduced Bufo marinus on American Samoa. Herpetol. Rev. 27(2):67-69.

ISAACS, P. \& HOYOS, J.M. 2010. Diet of the Cane Toad in different vegetation covers in the productive systems of the Colombian coffee region. South Am. J. Herpet. 5(1):45-50. http://dx.doi.org/10.2994/057.005.0105

ISACCH, J.P. \& BARG, M. 2002. Are bufonid toads specialized ant-feeders? A case test from the Argentinian flooding pampa. J. Nat. Hist. 36:20052012. http://dx.doi.org/10.1080/00222930110092153

JUNCÁ, F.A. \& ETEROVICK, P.C. 2007. Feeding Ecology of two sympatric species of Aromobatidae, Allobates marchesianus and Anomaloglossus stepheni, in central Amazon. J. Herpetol. 41(2):301-308. http://dx.doi. org/10.1670/0022-1511(2007)41[301:FEOTSS]2.0.CO;2

LACERDA, P., SARMENTO, A., MARQUES, A.M. \& ROCHA, C.F.D. 1998. Variação sazonal na diversidade, abundância e produtividade de artrópodos de uma área de Mata Atlântica do Sudeste do Brasil (Casimiro de Abreu, Rj), p 847-856. In VIII Seminário Regional de Ecologia. São Carlos, 1029p.

LAJMANOVICH, R.C. 1994. Habitos alimentarios de Bufo paracnemis (Amphibia, bufonidae) en el Parami medio, Argentina. Rev. Hydrobiol. Trop. 27(2):107-112.

LEAKEY, R.J.G. \& PROCTOR, J. 1987. Invertebrates in the litter and soil at a range of altitudes on Gunung Silam, a small ultrabasic mountain in Sabah. J. Trop. Ecol. 3:119-129. http://dx.doi.org/10.1017/S026646740000184X

LECLERC, J. \& COURTOIS, D. 1993. A simple stomach flushing method for ranid frogs. Herpetol. R. 24:142-143.

LEVINS, R. 1968. Evolution in changing environments: some theoretical explorations. Princeton University Press, Princeton. PMid:5742852.

MARAGNO, F.P. \& SOUZA, F.L. 2011. Diet of Rhinella scitula (Anura, Bufonidae) in the Cerrado, Brazil: the importance of seasons and body size. Rev. Mex. Biodivers. 82:879-886. 
Sabagh, L.T. et al.

MARTINS, A.C.J.S., KIEFER, M.C., SIQUEIRA, C.C., VAN-SLUYS, M., MENEZES, V.A. \& ROCHA, C.F.D. 2010. Ecology of Ischnocnema parva (Anura: Brachycephalidae) at the Atlantic Rainforest of Serra da Concórdia, state of Rio de Janeiro, Brazil. Zoologia 27:201-208.

PIANKA, L., OLIPHANT, M.S. \& IVERSON, Z.L. 1971. Food habits of albacore bluefin, tuna and bonito in California waters. Calif. Depart. Fish B. 152:1-350.

QUIROGA, L.B., SANABRIA, E.A. \& ACOSTA, J.C. 2009. Size-and sexdependent variation in diet of Rhinella arenarum (Anura: Bufonidae) in a Wetland of San Juan, Argentina. J. Herpetol. 43(2):311-317. http:// dx.doi.org/10.1670/07-117R2.1

SABAGH, L.T. \& CARVALHO-E-SILVA, A.M.P.T. 2008. Feeding overlap in two sympatric species of Rhinella (Anura: Bufonidae) of the Atlantic Rain Forest. Rev. Bras. Zool. 25(2):247-253. http://dx.doi.org/10.1590/ S0101-81752008000200013

SABAGH, L.T., FERREIRA, V.L. \& ROCHA, C.F.D. 2010. Living together, sometimes feeding in a similar way: the case of the syntopic hylid frogs Hypsiboas raniceps and Scinax acuminatus (Anura: Hylidae) in the Pantanal of Miranda, Mato Grosso do Sul State, Brazil. Braz. J. Biol. 70(4):955-959. PMid:21180899. http://dx.doi.org/10.1590/S151969842010000500006

SABAGH, L.T., MELLO, R.S. \& ROCHA, C.F.D. 2012. Food niche overlap between two sympatric leaf-litter frog species from Central Amazonia. Zoologia 29(1):95-98.

SAFFORD, H.D. 1999. Brazilian Páramos I: An introduction to the physical environment and vegetation of the campos de altitude. J. Biogeog. 26:693-712. http://dx.doi.org/10.1046/j.13652699.1999.00313.x

SAFFORD, H.D. 2007. Brazilian Páramos IV: Phytogeography of the campos de altitude. J. Biogeog. 34:1701-1722. http://dx.doi.org/10.1111/j.13652699.2007.01732.x

SANTANA, A.S. \& JUNCÁ, F.A. 2007. Diet of Physalaemus cf. cicada (Leptodactylidae) and Bufo granulosus (Bufonidae) in a semideciduous forest. Braz. J. Biol. 67(1):125-131. PMid:17505759. http://dx.doi. org/10.1590/S1519-69842007000100017
SANTOS, H., ROCHA, C.F.D. \& BERGALLO, H.G. 1998. A produtividade, diversidade e abundância de artrópodos do litter em dois segmentos de Mata Atlântica (Mata de Planície e Mata de Encosta) na Ilha do Cardoso, Cananéia, São Paulo. An. VIII Seminário Regional Ecol. 2:823-836.

SIQUEIRA, C.C., VAN-SLUYS, M., ARIANI, C.V. \& ROCHA, C.F.D. 2006. Feeding ecology of Thoropa miliaris (Anura, Cycloramphidae) in four areas of Atlantic rain forest, Southeastern Brazil. J. Herpet. 40(4):520-525. http://dx.doi.org/10.1670/0022-1511(2006)40[520:FEOTMA]2.0.CO;2

SOLÉ, M., KETTERL, J., DI-BERNARDO, M. \& KWET, A. 2002. Ants and termites are the diet of microhylid frog Elachistocleis ovalis (Schneider, 1799) at an Araucaria Forest in Rio Grande do Sul, Brazil. Herpetol. Bull. 79:14-17.

SUGAI, J.L.M.M., TERRA, J.S. \& FERREIRA, V.L. 2012. Diet of Leptodactylus fuscus (Amphibia: Anura: Leptodactylidae) in the Pantanal of Miranda river, Brazil. Biota Neotrop. 12(1): http://www. biotaneotropica.org.br/v12n1/en/abstract?inventory+bn00812012012 (último acesso em 03/06/2011).

TEIXEIRA-FILHO, P.F., ROCHA, C.F.D. \& RIBAS, S.C. 2003. Relative feeding specialization may depress ontogenetic, seasonal and sexual variations in diet: the endemic lizard Cnemidophorus littoralis (Teiidae). Braz. J. Biol. 63(2):321-328. PMid:14509854. http://dx.doi.org/10.1590/ S1519-69842003000200017

TEIXEIRA, R.L., SCHINEIDER, J.A.P. \& GIOVANELLI, M. 1999. Diet of the toad Bufo granulosus (Amphibia, Bufonidae) from sandy coastal plain in southeastern Brazil. Bol. Mus. Biol. Mello Leitão (N. Sér.) 10:29-31.

TOFT, C.A. 1980. Feeding ecology of thirteen syntopic species of anurans in a seasonal tropical environment. Oecologia 45:131-141. http://dx.doi. org/10.1007/BF00346717

TOFT, C.A. 1985. Resource partitioning in amphibians and reptiles. Copeia 1985:1-21. http://dx.doi.org/10.2307/1444785

WELDON, P.J., DEMETER, B.J. \& ROSSCOE, R. 1993. A survey of shed skin-eating (dermatophagy) in amphibians and reptiles. J. Herpetology 27:219-228. http://dx.doi.org/10.2307/1564942

ZAR, J.H. 1999. Biostatistical Analysis. Prentice-Hall, New Jersey. 